\title{
NÃO FALTA DINHEIRO À ADMINISTRAÇÃO PÚBLICA, FALTA GESTÃO
}

Coluna publicada em 31.7.2012: <http://www.conjur.com.br/2012-jul-31/ contas-vista-nao-falta-dinheiro-administracao-publica-falta-gestao $>$

"Governo tem 59 bilhões para investimento, mas não consegue gastar." A manchete do $O$ Estado de S.Paulo de 8 de julho de 2012 parece irreal. Ter dinheiro, e não conseguir gastar não soa verossímil. Mas é uma realidade bastante conhecida pela administração pública.

Gastar dinheiro público não é fácil e nem deve ser. Submetida a uma série de procedimentos e controles, com a louvável finalidade de evitar desvios e mau uso dos recursos públicos, a despesa pública é um ato complexo. Previsão legal no orçamento, licitações, empenho, cronogramas, liquidações, enfim, há um longo percurso até o desembolso.

Somente isso já mostra a necessidade de se ter uma administração pública preparada para operacionalizar o gasto público de forma rápida e eficiente, pois a liberação tardia do recurso pode até mesmo inviabilizar a finalidade para a qual seria destinado.

Infelizmente não é o que se verifica por uma série de razões.

De início, há que se observar que a gestão de recursos públicos está se tornando uma atividade cada vez mais complexa, a exigir pessoal especializado para cumprir esta que é uma atividade-meio, e não fim.

E a tendência natural é que cada Poder, órgão ou entidade que preste serviços públicos seja composto por servidores voltados à sua atividade-fim, para cumprir a função que deles se espera.

Assim é que em hospitais públicos espera-se encontrar médicos; em escolas públicas, professores; na segurança pública, policiais; no Judiciário, juízes; e em todos eles, os demais profissionais preparados para cumprir a finalidade para a qual os órgãos foram criados. 
No entanto, nesses órgãos as despesas públicas ocorrem o tempo todo e em valores expressivos. É evidente que não se pode esperar de médicos, professores e outros profissionais de áreas específicas conhecimento, experiência e desenvoltura, por exemplo, em realizar licitaçôes, sem contar todos os demais procedimentos próprios da complexa operacionalização da despesa pública.

Natural que ocorra o que se vem observando em toda a administração pública: a falta de profissionais especializados em gestão pública leva a um enorme desperdício de dinheiro. E não há que se falar desvios decorrentes de corrupção, apropriações indevidas e outros atos ilícitos. Uma lastimável perda de dinheiro que decorre pura e simplesmente de um fator: má administração.

Ainda mais lamentável é constatar que os recursos desperdiçados por má gestão são de grande monta. Valores que, embora praticamente imensuráveis, não sendo possível calcular com precisão, dão todas as evidências de que sejam extremamente expressivos. Não seria de se espantar, caso se pudesse chegar a um cálculo exato, de que venham a superar os decorrentes de corrupção e outros desvios. E mais: é extremante difícil responsabilizar agentes públicos por má gestão.

É de todo evidente que de nada adianta arrecadar mais se, na hora de gastar, os recursos são mal aplicados e não chegam ao seu destino. Já passou a hora de se voltarem os esforços, a energia e as preocupações para a despesa pública, e não para a receita.

A relação fisco-contribuinte já atingiu seu limite: os contribuintes não suportam mais a carga tributária, e o aumento da arrecadação só trará prejuízos ao cidadão e também ao país. Ademais, a administração pública, no que tange aos órgãos encarregados da arrecadação, estes sim, especialmente após as transformações que se observaram a partir da década de 1990, têm se informatizado, modernizado e aumentado sua eficiência, servindo de exemplo até para outros países. Não há por que priorizar a receita.

Portanto, passou a hora de conferir a mesma - ou até maior - eficiência aos órgãos que gastam o dinheiro público.

É verdade que a administração pública vem passando, já há algumas décadas, por processo de modernização. Novas técnicas de administração pública vêm sendo implantadas e, na década de 1990, houve uma intensificação desse processo. Embora ainda não consolidado, o processo de transformação de uma administração pública burocrática, mais preocupada com os procedimentos e a continuidade, em uma administração pública gerencial, mais moderna e eficiente, com gestores comprometidos com resultados e metas, é um caminho sem volta. 
A modernização do processo orçamentário, iniciada na década de 1960, com o orçamento-programa e as normas de planejamento da ação governamental, se tornou mais evidente a partir, principalmente, da Lei de Responsabilidade Fiscal, em 2000, com as novas exigências de coordenação e planejamento da administração pública.

A Constituição de 1988 e a estabilização da moeda em meados da década de 1990 permitiram a retomada do planejamento governamental - que se perdera no período de alta inflação -, com a exigência de um planejamento amplo e ao mesmo tempo eficiente, abrangendo todos os entes federados de forma coordenada.

As normas de planejamento, com a exigência de planos plurianuais, leis de diretrizes orçamentárias e orçamentos anuais com previsões precisas e confiáveis, e programas governamentais bem construídos, com resultados, metas e indicadores claros e factíveis, tornam a administração pública mais democrática e transparente. Obrigam o administrador a respeitar a vontade da sociedade, perseguindo os objetivos por ela traçados, e os submete a um controle social mais efetivo. Fazem-no pensar a longo prazo, evitando a descontinuidade das ações governamentais. E geram um comprometimento dos governantes com políticas de Estado e não políticas de governo, efêmeras e que não podem ficar restritas ao mandatário do momento.

Notam-se avanços. Os planos plurianuais têm se aperfeiçoado a cada nova edição, e as leis de diretrizes orçamentárias intensificaram seu papel como instrumentos de planejamento da ação governamental. Já há exigências de planejamento intragovernamental, como é o caso do Poder Judiciário, com a Resolução 70, de 2009, do Conselho Nacional de Justiça, que instituiu o planejamento estratégico nos tribunais.

O mesmo se pode verificar com o aumento da informatização e a introdução de técnicas mais modernas de gestão.

Há, no entanto, que se dar maior velocidade a esse processo que se mostra aquém das expectativas.

A maior parte da administração pública ainda não aderiu a ele, especialmente no âmbito de estados e municípios; a implantação das modernas técnicas de gestão, bem como a construção de uma administração pública com gestores profissionais, ainda é incipiente. Os Tribunais de Contas ainda não consolidaram a prática de fiscalizar a eficiência do gasto público, e ainda predomina, na maior parte deles, a análise meramente formal das despesas públicas, o que não se coaduna mais com as novas tendências da nova administração pública.

A informatização que já tomou conta da iniciativa privada não guarda correspondência na máquina pública, que segue atrás, muito mais lentamente do que se pode esperar. 
Há, portanto, muito o que fazer. E rápido, pois, enquanto isso, o dinheiro público - meu, seu e nosso - vai embora, sem que tenhamos o retorno devido em serviços públicos de qualidade.

Finalizo pedindo desculpas, em parte, pelo título desta coluna, em que estou ciente ter exagerado, sendo até incorreto, ao dizer que não falta dinheiro. É evidente que dinheiro também falta, e não é pouco. Por mais que se melhore a gestão, há muitos setores em que os recursos são escassos e, ainda que bem geridos, são insuficientes para atender a demanda para a qual foram criados. Mas creio que essa quase "licença poética" se justifica para chamar a atenção para aquele que é, hoje, o aspecto mais urgente e relevante na administração pública: aprimorar a qualidade do gasto público em todos os seus aspectos, tornando-o mais eficiente, com melhor relação custo-benefício, permitindo, assim, que os sempre e cada vez mais escassos recursos públicos sejam bem aproveitados.

É hora de se concentrar na despesa e não na receita, fazendo mais com menos. 